Vol. 4, $n^{\circ} 1 \mid 2000$

Varia

\title{
« Images of Poverty and Crime ». Police Memoirs in England and France at the end of the nineteenth Century
}

Paul Lawrence

\section{(2) OpenEdition \\ Journals}

Electronic version

URL: https://journals.openedition.org/chs/849

DOI: $10.4000 /$ chs. 849

ISSN: 1663-4837

Publisher

Librairie Droz

\section{Printed version}

Date of publication: 1 January 2000

Number of pages: 63-82

ISBN: 2-600-00433-5

ISSN: 1422-0857

Electronic reference

Paul Lawrence, " «Images of Poverty and Crime ». Police Memoirs in England and France at the end of the nineteenth Century", Crime, Histoire \& Sociétés / Crime, History \& Societies [Online], Vol. 4, nº 1 | 2000, Online since 02 April 2009, connection on 22 March 2022. URL: http://journals.openedition.org/chs/ 849 ; DOI: https://doi.org/10.4000/chs.849 


\title{
«Images of Poverty and Crime» Police Memoirs in England and France at the end of the nineteenth Century
}

\author{
Paul Lawrence'
}

This article attempts, via a comparative analysis of the memoirs of French and English policemen written around the turn of the century, to investigate police perspectives of and attitudes towards the poorer classes. Initially, a comparison is made between police views of the putative causes of indigent criminality and those advanced by mainstream social commentators. Then, police attitudes towards vagrants/mendicants are examined and contrasted with the assistance and tolerance granted to the so-called 'deserving poor'. It is concluded that while the social control functions of the police in both countries were evident in their dealings with the poor, police perceptions were nonetheless multi-dimensional. Pragmatism, empathy and practical assistance were as much in evidence as repression and suspicion.

En comparant les mémoires des policiers anglais et français, cet article examine les représentations et les attitudes des policiers à l'égard des classes les plus pauvres. Dans un premier temps on compare leur vision de la criminalité des indigents avec celle du courant dominant au sein des spécialistes de la question sociale. On étudie ensuite les attitudes policières concernant les vagabonds et les mendiants, qui contrastent avec l'assistance et la tolérance accordés aux "pauvres méritants». On en conclut que si, dans les deux pays, la fonction de contrôle social confiée à la police est évidente, les représentations policières sont cependant multi-dimensionnelles. Le pragmatisme, l'empathie et l'aide concrète sont aussi présents que la répression et le soupçon.

$\mathrm{T}$

he idea that both perceptions of crime and patterns of policing were still defined by issues of class at the turn of the century is by no means novel. Clive Emsley, writing about England, notes that «criminality tended to be seen as, essentially, a class problem ${ }^{2}$. This did not mean that indigence was necessarily regarded as the cause of crime, but it is certainly undeniable that poverty was seen as «the hallmark of most criminals». English commentators all perceived, to a greater or lesser degree, a fundamental conjunction between the poor and crime. As Gareth Stedman-Jones claims, the districts in which the poor lived had became

1 Paul Lawrence is research fellow in Modern History at the Open University. His current research involves a comparative study of the policing of the poor in England and France at the turn of the century. He also works on immigration and national identity in border regions of France during the inter-war period.

2 Emsley (1996, a, p. 56). 
«terra incognita», faceless yet threatening, where «the presence of an unknown number of the casual poor, indistinguishable to many contemporaries from criminals [...] constituted a disquieting alien presence in the midst of mid-Victorian plenty $»^{3}$. Similar attitudes can also be easily discerned in France. Many were quick to consider the poor as virtually synonymous with Frégier's «classes dangereuses» ${ }^{4}$. Jennifer Davis confirms that in France, popular and official anxieties concerning crime, 'increasingly focussed on the casual poor's . As a result of such apprehensions, policing in France and England naturally developed a focus firmly fixed on the casual poor of the major urban areas and on a class of habitual criminals believed to be recruited from their midst. Misdemeanours traditionally associated with the lower classes - petty theft and drunk and disorderly behaviour - took up large amounts of police time in both countries, while police involvement with offences relating primarily to the very poor, such as vagrancy and begging, also still formed a very significant part of police duties even at the turn of the century. Certainly a vast amount of police time, in both countries, was spent policing the poor and the very poor ${ }^{6}$.

This focus was doubtless at least partly due to a lack of police resources. Forces tended to concentrate their activities around limited geographical and investigative areas perceived as particularly troublesome. This in turn presumably meant that crime statistics reflecting the perceived criminality of the poor became somewhat self-fulfilling. However, it has also been largely assumed that the police shared prevailing societal attitudes and opinions pertaining to this putative criminality. The term 'assumed' is employed, because although statistical studies have been conducted in both countries, and an increasing body of work considers the experience of the poor at the hands of the police, comparatively little specific research has yet been undertaken into the attitudes and perceptions of the police concerning the poor and their presumed criminality. Partly, perhaps, this issue has been eclipsed by the debate surrounding theories of «social control». Robert Storch, for example, likened the advent of modern policing to «...the installation of the eyes and ears of ruling elites at the very centres of working class daily life», a view which appears to

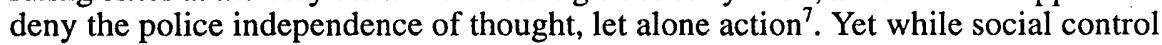
theory has now progressed and become gradually more subtle, there is still a perceptible tendency to marginalise the police as individuals. Emsley, among others, rightly contends that 'the simple division which posits a ruling class making and administering the law, and a ruled class on the receiving end, obscures the often marked differences between agents of the law and prosecutors' ${ }^{8}$. This is likely to be particularly true when the 'victimless' offences most commonly associated with extreme poverty (mendicity and vagrancy) are considered. The legislation associated with such offences was often « vague and generic, allowing in practice considerable discretion in their interpretation $"$.

3 Stedman Jones (1976, p. 14).

4 Frégier, (1840).

5 Davis (1991, p. 2).

6 For statistical data for London and Paris see, for example, the annual «Report of the Commissioner of Police of the Metropolis » contained within the British Parliamentary Papers, and Archives de la Préfecture de la Police, $B^{A} 1567$, Crimes et Délits.

7 Storch (1976, p. 496).

8 Emsley (1996, a, p. 10).

- Thompson (1981, p. 197). 
Thus the object of this article is to investigate some of the perspectives and perceptions which police officers held of the poor. The assessment of opinion is always a problematic issue. It is rarely coherent among any given group of individuals, is often transient and can occasionally be intentionally obscured. However, the memoirs, autobiographies and policing manuals written by retired officers in France and England, utilised here and pertaining in the main to the end of the nineteenth century, are a diverse, potentially fruitful and often disregarded source of material ${ }^{10}$. Authors range from the distinguished (Louis Andrieux was a prefect of the Paris police), to the more humble (Émile Forestier began his career as a gendarme) - and everything in between. Some had risen through the ranks to prominence (Macé and Goron were anciens chefs de la Sûreté and William Chadwick was a Chief Constable), while others had less remarkable careers (Benjamin Leeson was a detective and Louis Hamon a simple commissaire de quartier). Geographically, too, their experiences were diverse. Caubet was a Chef de la Police Municipale in Paris, while James Bent had policed a rural beat in the north of England. Also, while most of the memoirs cited here were written in the period $1885-1900$, some slightly later works have been included to allow for a measure of cross-generational comparison.

The backgrounds, both professional and social, of the authors, as well as their literary styles were thus evidently by no means uniform. However, this very multiplicity can also be viewed as an advantage in this case. It is possible to discern a remarkable congruence of attitudes among police officers concerning the poor, a correspondence which often transcends nationality, age and professional positions. Obviously the historian must view such documents with perhaps more than routine scepticism. These are not operational reports and many accounts are impressionistic and anecdotal. All claim, like Gustave Macé, to expose «la verité, toute la vérité, rien que la vérité » yet, while the days of Vidocq may have been long past, these volumes were sold as literary entertainment and certainly contain sensational and questionable passages ${ }^{11}$. Nevertheless, alongside the melodramatic these memoirs also contain a wealth of incidental detail, a proportion of which inevitably pertains to the poor. Via the prism of this anecdotal data it is possible to investigate specific areas of police opinion. Societal attitudes towards the presumed criminality of the poor were undergoing change throughout the nineteenth century as individual, moralistic explanations ceded ground to more collective, scientific theories and this process is delineated in section I via reference to mainstream social commentators. In section II the views of police officers concerning criminality among the poor are evaluated and contrasted with these general perceptions. Subsequently, police attitudes towards vagrants and beggars, which are highly reflective of contemporary social anxieties and the need for défense sociale, are compared to the authors' perceptions of the supposed 'deserving' or honest poor ${ }^{12}$.

10 Exceptions include Becker (1994), who draws on similar source material for an article on the German police and Berlière (1991\&1996), who also makes good use of French autobiographies. Macé $(1885$, p. 2$)$. 
For much of the period to 1900 , it can be stated categorically that «most experts and commentators went out of their way to deny any relationship between low wages, poverty and the bulk of crime ${ }^{13}$. In both England and France it was common to view the causes of both poverty and crime as intrinsic to the individual rather than collective and inherent within society. In 1839, the English Royal Commission on a Constabulary Force had concluded that "the notion that any considerable proportion of the crimes against property are caused by blameless poverty we find disproved at every step " ${ }^{14}$. Similarly, in 1876 , the commentator William Hoyle still considered that the expansion of international trade coupled with wages increases had «almost annihilated every possible excuse for the commission of crime on the plea of want ${ }^{15}$. Instead, explanations of both poverty and criminality tended to emphasise the role of personal morality and the corrupting influence of idleness and vice. Partly due to a perpetuation of the antiquated distinction between deserving and undeserving poor, and partly due to the deficiency of contemporary economic theory, poverty was commonly seen as the end result of lax personal morality. If penury resulted in crime, this was still therefore the fault of reasoning individuals who were held responsible for their own social indigence. Thus William Tallack, writing about «pauperism and crime" could insist that 'their causes are admitted to be, mainly, [...] Intemperance, Improvidence and Ignorance ${ }^{16}$. Vice, particularly the temptations of drink, was particularly seen to lead individuals first into poverty, and then on to criminality. A report on the Preston House of Correction claimed that 'the passion for intoxicating drink is the cause of almost all crime and misery done or suffered by the working classes ", for it was in pubs that they were exposed to «not only the incentives to the sin of drunkenness », but also «invitations to fouler crimes ${ }^{17}$.

In French thought too, there was a clear tendency to associate the poor with criminality, but again to ignore explanations based on economic causation in favour of those stressing personal responsibility. Henri Joly, for example, claimed that crime was a «maladie morale», maintaining that while economic crises were occasional, theft was constant, and that 'it would be easier to acquit human nature and to blame economic circumstances, if years of plenty lowered criminality as much as years of bad harvest raised $i^{\prime 18}$. Via this somewhat tenuous logic he thus concluded that poverty and crime were not intrinsically linked. Similarly Prosper Despine was quick to accent the role of morality (or rather its absence among the poor) in the origins of criminality. While acknowledging that drunkenness was not confined to any one class, he also believed that l'ivrognerie was a «compagne fidèle» to the

13 Emsley (1996, a, p. 58).

14 Royal Commission on a Constabulary Force, Parliamentary Papers (1839), XIX, 73, (Para. 65).

is Hoyle (1876, p. 87).

16 Tallack $(1869$, p. 9).

17 Clay (1853, p. 34).

18 Joly $(1889$, p. 359$)$, «il serait plus facile de décharger la nature humaine et d'accuser les circonstances économiques, si les années d'abondance abaissaient la criminalité autant que les années de mauvaise récolte l'élèvent ». For further information on Joly see Veitl (1994). 
poor. Such individuals were then drawn to crime «because alcohol has destroyed all moral sensibilities and replaced them with the most appalling instincts ${ }^{19}$.

However, attitudes were changing rapidly at the end of the nineteenth century. Such individualistic explanations of the links between poverty and crime were undergoing modification, and increasingly ground was being ceded to more collective theories of degeneration and urban decay. Although most commonly associated with the work of the Italian criminologist Lombroso, Daniel Pick has demonstrated that in fact this diffuse and ill-defined discourse had a European-wide impact ${ }^{20}$. Thus the criminological debate, for some writers, moved away from questions of individual choice/blame into the realm of collective decay as attempts were made to define the criminal not just socially but also physiologically. As Pick expresses it, «degeneration was increasingly seen by medical and other writers not as the social condition of the poor, but as a self-reproducing force; not the effect but the cause of crime, destitution and disease ${ }^{21}$.

Interest in the concept of degeneration and its possible links with poverty and crime were perhaps more pronounced in France than in England. Charles Féré, for example, was a doctor and much of his work Dégénérescence et Criminalité is an analysis of the poor of Paris and the quarters where they lived ${ }^{22}$. For Féré, the poor were those individuals who had failed to adapt (both mentally and physically) to a rapidly changing industrial society, and had thus fallen prey to criminality and illness. He was certain that «extreme poverty and its faithful companions, crime and sickness, can never disappear, as they are continually nourished by the exhaustion which results from the increasingly extreme strains of adaptation ${ }^{23}$. Similarly, Alfredo Niceforo also noted that « organic degeneracy is one of the most important components of criminality », and thus it was «a mistake to think that poverty only leads to crime via need, temptation and hunger $»$. In fact, in his collectivist opinion, «destitution creates criminals because it creates degenerates ${ }^{24}$.

As for the other side of the channel, Pick notes that «there is no sense of a 'founding text' of degeneration or atavism in England ${ }^{25}$. Yet although a specific language of decay might have been less evident, there was nonetheless a growing interest in the corrupting influences of urban life on the poor and the relationship of this to their perceived criminality. Many texts reveal a shift towards a more collective view of both poverty and crime, linking the two via the perceived causative determinant of urban degeneration. Francis Peek observed in the 1880s that «many families in London [...] have only one single room, in which parents and children of

19 Despine (1871, p. 46), «parce que l'alcool a détruit tous les sentiments moraux et les a remplacés par les instincts les plus détestables».

20 Pick (1989).

21 Pick $(1989$, p. 21).

22 Féré (1888).

23 Féré (1888, p. 124), «la misère et ses satellites fidèles, le crime et la maladie, ne peuvent disparaître, sans cesse alimentés qu'ils sont par l'épuisement qui résulte de l'exagération croissante des efforts d'adaptation".

24 Niceforo (1907, p. 416), « la dégénérescence organique est un des plus importants facteurs de la criminalité », "une erreur de croire que la misère ne pousse au crime qu'à cause de besoin, de la tentation et de la faim», «la misère est une grande créatrice de criminels parce qu'elle est une grande créatrice de dégénérés ».

Pick (1989, p. 176). 
all ages and both sexes work, live and sleep». He concluded that it was «impossible that children brought up thus can fail to become unhealthy in body and depraved in mind and morals ${ }^{26}$. Similarly, the Reverend W.D. Morrison, one time Chaplain to Wandsworth Prison, believed that while it was «still a mistake to assume that crime is entirely a product of economic adversity », it was nonetheless true that «the ordinary man» was «deteriorated» when placed under abnormal economic conditions. Eventually these «adverse conditions» would «prevent him from obtaining a proper amount of physical nourishment » and that the resultant «physical deterioration » was often «the prelude to mental degeneracy » and hence criminality ${ }^{27}$.

Thus at the turn of the century the poor were still routinely associated with crime and criminality by many sections of society in both England and France. Although the perceived causes of criminality among the poor were perhaps shifting from an emphasis on individual morality to the consideration of theories of collective degeneracy, the role of continual, extreme poverty in necessitating crime had never been acknowledged and certainly the very identification of the poor with the majority of crime remained largely unchallenged. It is against this background, albeit briefly demarcated, that an analysis of the attitudes of senior police officials may prove instructive. Did the police generally view the poor as a «criminal class»? If so, why? Certainly, police claims to professionalization were in part based on their hypothetical capacity of «seeing through" subterfuge, and of identifying criminals and the underserving poor where others could not. Did they then subscribe to the general trends outlined above, or was it perhaps the case that the everyday contact of the police with the poorer elements of society engendered a more nuanced, less hysterical outlook?

II.

Certainly many officers did perceive a relationship between socio-economic, collective factors, such as poverty, and crime. Ex-CID detective Frederick Wensley claimed that "with very few exceptions criminals are made by environment and circumstances ${ }^{28}$. Yet he also noted with sympathy that «it is not always their fault that conditions have moulded them wrongly", and the correlation between poverty and crime was by no means regarded as predestined or universal. Many, like Tom Divall (an ex-CID chief) demonstrate an awareness that while environmental factors were an important component of nascent criminality, the poor were not the only criminals. Divall cites a conversation with a wealthy family man in the waiting room of a magistrates court. He told the culprit that the exposure and disgrace would again bring terrible sufferings and hardships on his wife and family, but relates that despite his wealthy status, «his only reply was that crime was too captivating and exciting for him to resist it ${ }^{29}$. In other memoirs ex-police officers seem positively keen to correct public perceptions of the poor as a criminal class. Goron, ancien chef de la Sûreté told his readers rather loftily that «humanity is rather better than the philosophers allow ». Writing of his early experiences policing the rough outskirts of Paris

\footnotetext{
26 Peek (1883, p. 21).

27 Morrison (1896, p. 173).

28 Wensley $(1931$, p. 288$)$.

29 Divall $(1929$, p. 87).
} 
he noted that « when one sees this gaudy population, spreading its rags in the middle of tottering shacks and crumbling houses», it is perhaps natural that «one forms a sinister impression ${ }^{30}$. In fact, his experience showed that among these unfortunates there were individuals who possessed «a probity more scrupulous than many gentlemen one might greet in the street».

It should not be forgotten that the authors of police memoirs and autobiographies would have been keen to give a favourable impression of themselves to the reading public. Yet there seems little doubt that many harboured a genuine sympathy for elements of the poor and did not perceive them merely as a semi-criminal class forever estranged from the rest of society. However, if most police officers did recognise some sort of effectual correlation between poverty and crime but did not believe that all of the poorer elements of society were criminals (or even potential criminals), what then did they regard as the nature of the causative link?

In common with other observers, few policemen authors subscribed to a simple, deterministic theory of indigent criminality, i.e., that the poor were forced into crime (particularly theft) by necessity and the need to make ends meet in an era before comprehensive welfare provision. Certainly Louis Hamon, a Paris commissaire during the 1880s, believed that «poverty and hunger are, without doubt, for men, the biggest determinants of criminality», yet most officers tended to veer away from economic explanations of criminality among the poor ${ }^{31}$. Macé, for example, believed that increasing levels of crime had «undoubtedly been created by the perpetual temptation which department store create for the Parisian ", and that in fact most thefts were «committed out of temptation rather than need ${ }^{32}$. Putting an emphasis firmly on personal morality, Macé claimed that the excuse of poverty was rare and that those who stole were generally unruly and pleasure seeking. Indeed he concluded that only one thief in a thousand was acting out of need or desperation. However, few other officers acceded to his simplistic view that criminality among the poor was merely the result of a lack of will-power.

It was rather more common for police memoirs to stress the corrupting influence of vice, particularly excessive consumption of alcohol, and its relationship to both poverty and crime. Superintendent James Bent, for example, cites the case of a man "who had seen better days, but who had become thoroughly depraved and reduced to poverty through drink», and was subsequently imprisoned on theft charges ${ }^{33}$. Bent's attitude towards the culprit seems far less sympathetic than in other, nondrink related cases, claiming that «he was a lazy, drunken fellow, and would not work». Certainly in Bent's opinion, drink led to poverty, and the two combined often led eventually to crime. In France, too, there was concern among the police about the putative inducements to crime generated by the combination of alcohol and poverty. Commissaire Boué claimed that $80-100 \%$ of all those arrested on

30 Goron (1897, p. 139), «l'humanité est bien meilleure que ne le disent les philosophes», «quand on voit toute cette population bariolée, étalant ses guenilles au milieu de cabanes chancelantes et de maisons lézardées», «on éprouve une impression sinistre», «une probité plus scrupuleuse que bien des Messieurs qu'on salue sur le boulevard ».

31 Hamon (1900, p. 341), «l'indigence, la faim sont, sans doute, pour les hommes, les grands facteurs de la criminality ».

32 Macé $(1887$, p. 259), «a été créé incontestablement par la tentation perpétuelle qu'est pour la Parisienne le grand magasin de nouveautés », «commis par tentation et non par besoin ».

33

Bent (1891, p. 49). 
charges of mendicancy or vagrancy were found to be drunk but, like Bent, regarded drunkenness as a cause of both poverty and crime rather than a likely side-effect of the former and a possible constituent of the latter ${ }^{34}$. Boué maintained that the poor saw themselves shunned everywhere due to their ignoble passion for alcohol until eventually, degraded and stupefied, they reached the bottom of society. The self-destructive excesses of liquor led to poverty and then criminality as fainéant and débauché the individual «never works and steals to satisfy his/her craving for alcohol».

Other officers were, however, more tolerant. Benjamin Leeson, a detective in London's poor «East End », also stressed the close links between drink, poverty and crime, noting that at the end of the nineteenth century, «drink was the chief cause of the squalor and crime of those days $»^{35}$. Nevertheless, he displayed a little more empathy than Bent and added the caveat that, of course, «it must be remembered that these people of the East End had very little alternative to the public house in the way of amusement ». Similarly Richard Jervis, a Lancashire Superintendent, writing about Ormskirk complained that «[t]he worst conducted houses [public houses] were in the neighbourhood of slum property, and were little more than miserable drinking dens, lending an air of truth to the assertion [...] that slums, drunkenness, and crime are inseparable. How can it be otherwise? ${ }^{36}$. Yet he, too, evinced a certain level of compassion and realised that 'few of us so circumstanced would have found it easier to have said: "Get thee behind me, Satan!»" Alcohol abuse was linked by the police to poverty and thence to crime but many officers (particularly among the English) were remarkably non-judgemental, in print at least ${ }^{38}$.

Gambling was also cited by policemen in both France and England as a precursor to both ruin and criminality, but drink was seen as by far the most dangerous vice. Despite this, a predilection for drink was not always seen as a weakness solely afflicting the poor, nor was alcoholism perceived purely in terms of deficient personal morality. In many memoirs there is an indirect stress on the environment within which the poor lived and on the corrupting influences of slum life. The poorer classes, it was felt, were often constrained to live in close proximity to vice and crime and, in keeping with contemporary theories of urban degeneration, this was seen to have an inevitably detrimental effect on them both morally and physically. Given life in such districts, opportunities for crime were rife and temptations to dishonesty were hard to resist for the poor. Many police officers thus believed that « the savage and brutalised condition of the casual poor", and hence a certain predisposition towards criminality, was «the result of long exposure to the degenerating conditions of city life ${ }^{39}$. Although generally incognizant of the specific terminology of the degeneration debate, many memoirs demonstrate a specific concern with the continual corruption of new generations of poor children brought up in harsh city environments.

34

Boue (1906, p. 25), «ne travaille jamais et vole pour satisfaire sa passion pour l'alcool ».

Leeson (1931, p. 118).

Jervis $(1908$, p. 72).

Jervis $(1908$, p. 72$)$.

Indeed, it might be argued that few were in a position to adopt the moral high ground. The work of Emsley (1996b) and Berlière (1996) has shown that drunkenness was a common problem among the police in both England and France.

Stedman Jones (1976, p. 286). 
Leeson, writing again of Whitechapel, noted that the destitution of the area meant that «except for casual employment at rare intervals at the docks or factories there was no honest work [...] in this district ${ }^{40}$. Describing one particular «alley » he wrote that « with its score or so of dilapidated houses, or rather hovels », it was «a perfect hotbed of criminality and criminals $»$. He claimed that children of eight and nine years of age had been brought from this alley «to be charged with burglary, robbery, housebreaking", and in fact all manner of crime with the exception of murder « which last they left to their elders and betters ». Thus he concludes that in destitute areas «crime was both cultivated and stimulated in young children ». Such views, with implicit overtones of degeneration theory, were not uncommon. Chief Constable Henderson similarly noted that «children born in such places are generally puny and delicate, many of them growing up unfit for manual labour, and are driven either to crime or begging for a livelihood ${ }^{41}$.

While such theories are not so pronounced in French police memoirs, there is still an evident appreciation of the problem of juvenile delinquency among the poor, and a measure of sympathy for indigent children deteriorating on the periphery of nineteenth century society. Caubet, for example, referred to the "precocious products of laziness and depravation, children in age but seasoned by depravity » whom he considered «the dangerous wreckage of an incomplete civilisation, which leaves poor, abandoned children to grow and develop in the mud of the gutter $\gg .^{42}$ These children thus became corrupt urchins, riddled with vice and capable of the worst deeds. Likewise Goron, too, expressed sympathy and official concern over the innumerable street children, «thrown without principles, without moral guidance into a society where the struggle for survival seems the only law ${ }^{43}$.

Thus it would appear that there was a discernible convergence of police attitudes towards indigent criminality on both sides of the channel. The policing of the poor as demonstrated by arrest figures for vagrancy, begging, petty theft and minor public order offences - claimed the lion's share of police activity and meant that the poor were obviously associated with many types of crime by the police. However, the routine, daily contact between the two usually negated any inclination towards sweeping generalisations concerning the conjectural correlation between poverty and crime. Daily traversing the «terra incognita» of Paris and London, police officers realised that most of the faceless and terrifying «classes dangereuses» were in fact hard-working and honest. Of those who did become associated with crime, few policiers adopted a simplistic "poverty $=$ need $=$ crime» equation. Far more common was a sympathetic stress on the harshness of the urban environment and the potential for contamination by enforced proximity to hardened recidivists, particularly for destitute children, surrounded by both temptation and squalor. Yet the perceived relationship between poverty and crime was not always impersonal and collective and in common with civilian commentators, many officers also referred

40 Leeson (1931, p. 117).

41 «Report of the Commissioner of the Police of the Metropolis, 1875»-Parliamentary Papers, 1876, XXXIV.315.

42 Caubet (1893, p. 175), «précoces produits de la paresse et la dépravation, enfants par l'âge, vieux par la perversité», «les dangereuses épaves d'une civilisation incomplète, qui laisse des enfants pauvres et abandonnés grandir et se développer dans la boue des ruisseaux ».

43 Goron (1897, p. 403), «jeunes fauves, jetés sans principes, sans éducation morale dans une société où la lutte pour la vie semble être la suprême loi ». 
to the debilitating effects of alcoholism, which was often perceived as a cause of both poverty and crime. Only a few were clear sighted enough to recognise such abuse as a possible result of poverty rather than its source, and in general policemen were intolerant of such excess among the poor and still considered it indicative of lax and self-destructive personal morality.

However, the police were still perhaps more aware than other commentators of the differentiations to be made among «the poor». As Robert Schwartz notes with reference to the previous century, policemen on the spot drew «finer distinctions among the poor» than other commentators. To see things through the eyes of a constable « is to catch a glimpse of the poor as they appeared in streets and markets, at the portals of churches, on the roads $»^{44}$. Thus it is perhaps apposite to attempt to examine some of the divisions made amongst the poor by the police, and to analyse the attitudes and perceptions meted out to each putative «type».

III.

Vagrancy was usually mentioned, albeit perhaps in passing, in almost every police memoir examined. The term "vagabond/vagrant» was similar in both countries, although in France from 1895 onwards the expression «clochard» was increasingly employed, and occasionally the designation S.D.F. (sans domicile fixe). Regardless of terminology, to be without a home, a job and adequate resources was still an offence in both England and France at the end of the nineteenth century, and the administration of vagrancy legislation occupied a large tranche of police time. Despite gradually declining arrest figures in both France and England, vagrants were perhaps the most unpopular of all elements of the poor.

Police officials in France were virtually unanimous in their dislike of vagrants and made little effort to disguise their opinions. Presumably most were sure that their readers would share such attitudes, adroitly summarised by Macé when he claimed that «every vagabond has the makings of a criminal and will become one sooner or later ${ }^{45}$. Of all the readily identifiable sub-groups of the poor, vagabonds were the most often viewed as 'set apart' from the rest of society by the police. As Patrick Gaboriau observes, many believed that the vagabond threatened l'ordre social and that society needed to protect itself from such individuals ${ }^{46}$. Pierre Boué, for example, noted that «in a region infected by vagabonds [...] its was our duty to protect the inhabitants of the towns against the misdeeds of these unscrupulous individuals ${ }^{47}$. Boué's choice of the word «infectée » with its overtones of pollution and decay is instructive, and it was certainly common to assume the criminality of vagrants and tramps. Macé claimed that «it is among these fourlines that the perpetual recruits of vice and crime are drawn ${ }^{48}$. In the first volume of his memoirs he

44 Schwartz (1988, p. 4).

45 Macé $(1885$, p. 271), «tout vagabond possède l'étoffe d'un malfaiteur et le devient tôt ou tard».

46 Gaboriau (1998, p. 31).

47 Boué (1906, p. 8), «dans une région infectée de vagabonds [...] il était notre devoir de prévenir les habitants $[\ldots]$ des villes contre les méfaits de ces gens sans scrupules ».

48 Macé (1887, p. 181), «c'est parmi ces 'fourlines' que s' alimentent les recrues, toujours nouvelles, du vice et de crime». 
goes into greater detail, subdividing vagabonds into various categories, but his overall conclusion is still that «in essence [...] vagabonds are a veritable open wound within society and a continual danger to the safety of the public and their property ${ }^{49}$. Again the use of the term «plaie», with its overtones of corruption, implies a distinct sense of revulsion.

Allied with vagabonds, and in fact generally receiving even greater animosity, were gypsies ${ }^{50}$. Where vagrants were concerned there was at least the possibility that they were in actuality honest labourers down on their luck, but the caravans and clothing of gypsies immediately identified them as wanderers by choice and the French police seem to have assumed, mostly without question, their innate criminality ${ }^{51}$. A police circular from as late as 1907 instructed officers that 'concerning the bands of nomads known under the generic term romanichels, I remind you that they are all too often composed of criminals', and such prejudices are clearly reflected in police memoirs ${ }^{52}$. Macé in particular emphasised the theme of gypsies as a race apart, claiming that «easily identified by their strongly marked features and their dark complexions», and "belonging to no nationality in particular», they «hate all with equal ferocity, and pass their existence defying the laws of every well-governed people under the sun ${ }^{53}$. Boué, too, concurred that «the character of these people is wily, cowardly, cruel and vindictive" and thought that they trained their children from infancy in the art of begging and theft ${ }^{54}$.

The French police were by no means alone in embracing such presumptions, as Leo Lucassen has demonstrated via his analysis of the German police ${ }^{55}$. Certainly when the English case is considered, although Stephen Inwood claims that the Metropolitan Police «regarded the policing [...] of vagrancy as one of their more delicate and difficult tasks », evidence from other sources suggests that the police in England by no means relished contact with itinerants ${ }^{56}$. It is likely that some chief constables, particularly those in rural areas, retained a perception of the tramp as a potential criminal, or at least as a suspicious character until well into the early twentieth century. Jervis noted that his first case involved a vagrant and stated that henceforth he 'made almost a special feature of stopping and searching tramps and suspicious-looking characters on the road' and that 'the results justified the means a great many did I pick up with stolen property in their possession' ${ }^{57}$. Cheshire Chief Constable William Chadwick, too, was firmly convinced as to the criminal nature of the majority of vagrants, referring to them as «this social blot on our civilisation»,

49 Macé $(1885$, p. 271$)$, «en résumé [...] les vagabonds sont une véritable plaie sociale et un danger permanent pour la sûreté des citoyens et de leurs biens ».

Gypsies were also referred to as «nomades'» «bohémiens» and «romanichels ».

See Berlière (1991, p. 355).

Archives de la Préfecture de la Police, $D^{B} 200$, Circulaire ministérielle, Direction de la Sûreté Générale to Commissaires, 27/7/07, «en ce qui concerne les bandes des nomades désignés sous le terme générique de romanichels, je vous rappelle qu'elles sont trop souvent composées de malfaiteurs». The same circular also recommended «la surveillance la plus active».

Macé (1888, p. 25).

Boué (1906, p. 47), «le caractère de cette population est astucieux, lâche, cruel et vindicatif».

Lucassen (1997).

Inwood (1990, p. 141).

Jervis (1908, p. 14). 
and «the scum which floats on the surface of our social system ${ }^{58}$. Police officers in England also often acted as Poor Law Relieving Officers. This involved the distribution of tickets for the casual wards of work houses and was not a task they appreciated. The Chief Constable of Surrey noted that a number of his men wished to be released from this duty «as a consequence of the exceedingly troublesome nature of the appointment $»$ and the Commissioner of the Metropolitan Police also concurred that «the casuals are a nuisance and an annoyance to the police» and that «the contact of the Police with the Casuals as Relieving Officers is [...] very distasteful to the Police ${ }^{59}$.

Thus the attitudes of the English Police, too, in many ways reflected the popular prejudices of contemporary society, in that 'the respectable classes' customarily viewed «the homeless and workless who congregated in the casual wards » as occupying «a borderland between indigence and criminality ${ }^{60}$. Certainly, as David Jones asserts, «so far as we can tell from the evidence there was very little police sympathy for these poor members of society ${ }^{61}$. However, it does appear that, in print at least, the British police were not so sweepingly vitriolic in their assessment of the potential criminality of vagrants as the French. Certainly attempts to categorise and classify vagrants as "potential » criminals were prevalent to a greater extent in French memoirs. It should also be noted that the French police generally found vagrancy more of an intractable problem than their English counterparts. In 1892, for example, the Paris police arrested over 17,000 vagabonds while in London the total number of arrests under the vagrancy legislation was only 4,300 - despite the fact that the population of London was roughly double that of Paris ${ }^{62}$. While police perceptions of the itinerant were similar in both countries, there were discernible differences in scale.

The more overt animosity of French officers was also perhaps partly due to the fact that the evolution of different welfare systems meant that the comparative roles of the police in respect to vagrants also varied in each country. Vagrancy was a criminal offence in both countries, but the corresponding mechanisms for dealing with itinerancy differed. In France the police were essentially alone in dealing with the problem. Vagrancy was perceived to be primarily a policing issue and whenever matters rose to a head, it was always the commissaires and gendarmes who were pressed into service ${ }^{63}$. The Dépôts de Mendicité and hospitals accepting vagrants were few in number and vastly under-resourced and hence, following arrest, those

58 Chadwick (1900, p. 128).

59 First quote: Surrey Record Office - CC/98/3/29. Chief Constable's Office Correspondence Register, 1861-1969, Letter dated 11/1/1869 - number 3100. Second quote: «Report of the Commissioner of Police of the Metropolis, 1869 » in Parliamentary Papers, 1870, XXXVI.461.

60 Englander (1998, p. 33).

61 Jones (1982, p. 207).

62 London Arrest Statistics - «Report of the Commissioner of Police of the Metropolis, 1892», Parliamentary Papers, 1893-94. Paris Arrest Statistics - A.P.P., B ${ }^{A} 1567$ Yearly Arrest Statistics. It should be noted, however, that there were some years in which police repression (and hence arrest figures) was much higher - specifically, 1880-1, 1889 and 1895 .

63 Indeed there was much more of a tradition of arresting vagabonds and gypsies in France than in England. The Maréchaussée had competence over them from at least the Edict of Paris $\left(25^{\text {th }} \mathrm{January}\right.$ $1536)$ and Schwartz (1988) notes how this role was consolidated and expanded during the $18^{\text {th }}$ century. 
vagabonds not released to members of their family were held in police cells prior to a court appearance. Any not sentenced to imprisonment were usually released onto the streets, often only to be re-arrested again a few days later. The lack of a viable alternative to the criminal justice approach to itinerancy must have meant that, despite calls during the 1890 s for the establishment of workhouse-style places of refuge, the police bore most of the responsibility for the regulation of vagrancy in France. In England, the Houseless Poor Act of 1864 had attempted to improve the casual wards of workhouses, and in 1871 the possibility of detaining recalcitrant vagrants had been introduced. The overall effects of this legislation may not have been dramatic, but the presence of a basic state welfare structure must have meant that police contact with vagrants was lessened. Except for hardened recidivists, the place for vagrants was in the workhouse and the responsibility of the police was principally to deliver them there. The English police no doubt found contact with such individuals distasteful, but statistics show that vagrancy was less of an irritant to the police on this side of the Channel, who were able to maintain a distance from the problem unavailable to the French. Despite this, it should again be noted that the differences in attitude between the French and English police were primarily ones of scale and intensity. The basic perceptions of vagrants, and indeed itinerants in general, remained remarkably congruent in both countries. It is likely that in this desire to control vagrants and to exercise what Kalifa refers to as a "prophylaxie sociale», the police in both countries were merely reflecting current societal trends ${ }^{64}$. The ongoing development of modern, urban society with its relatively durable economic interrelationships was increasingly leading to a fear of mobility and the problems it could cause, and a concomitant desire for identification and stability ${ }^{65}$. Repressive police attitudes towards vagrants must thus be viewed alongside other initiatives with similar aims, including the Bertillon system of bodily measurement (for identifying recidivists), the creation of the brigades mobiles to track offenders across the country and the introduction of the carnet anthropométrique for itinerant gypsies.

Where beggars were concerned there was again a high degree of convergence of police attitudes on both sides of the channel. Many were convinced that numerous beggars and mendicants were not in a genuine state of fiscal desperation and it was common to blame the public for this. Henderson noted in 1872 that «indiscriminate charity now as ever creates and sustains a class of people whose vocation is not to labour $"{ }^{66}$. Chadwick too felt that a large majority of beggars made a comfortable living, «not so much by their own wit as by the want of wit in others who allow themselves to be imposed upon by all sorts of pitiful tales ${ }^{67}$. In France, Boué also agreed that «if society has a duty to come to the aid of the poor, it also has the strict obligation to give chase to professional beggars ${ }^{68}$. Clearly reflecting popular

64 Kalifa (1994, p. 235).

65 For further information on the marginalisation of the vagrant within modern French society, see Wagniart (1999).

66 'Report of the Commissioner of Police of the Metropolis, 1872', in Parliamentary Papers, 1873, (1874), XXVIII.313.

67 Chadwick (1974, p. 128).

68 Boué (1906, p. 59), 'si la société a le devoir de venir au secours des pauvres, elle a aussi le devoir strict, de donner la chasse aux mendiants de profession', 'les distributions qui se font aux portes des particuliers [...] manquent du discernement indispensable pour éviter l'encouragement de la paresse, et soulager la misère véritable'. 
opinion he perceived indiscriminate charity to be part of the problem, not a solution, and also observed that «the handouts which take place on doorsteps [...] lack the discernment necessary in order to avoid encouraging laziness, and to relieve real poverty".

Some memoirs also reflect the contemporary urban myth of the «rich professional beggar». Gendarme Ignace-Émile Forestier relates his arrest of a mendiant de profession who, although hale and hearty, had decided to live at the expense of society and had in his possession a wallet containing over 700 francs $^{69}$. Yet officers also recognised that there were cases of real need. In one anecdote Bent relates how he arrested an ex-soldier for begging but discovered that he had been unable to obtain relief in the parish of his birth. The soldier then told Bent «I shan't be brought up for begging any more. I'll have what I want, where I can get it ». Bent warned him not to steal, but was forced to concede that he felt sorry for the soldier and concluded that «we ought to provide for such as you better than we do ${ }^{70}$.

Other officers also felt that the welfare systems in their respective countries were not equal to the task. In France, for example, Boue concluded that the right to arrest beggars correspondingly implied the obligation to widen access to public assistance. $\mathrm{He}$ felt that 《it is shelters and hospices which should be opened and not prisons ${ }^{71}$. Such an attitude perhaps runs somewhat counter to Timothy Smith's claims that most French commentators believed that « legal charity would institutionalise pauperism», but the police on both sides of the channel realised that the situation was not so clear cut $^{72}$. Most were suspicious that not all beggars were genuine and many shared public perceptions that indiscriminate charity served only to create a class of individuals who thrived on counterfeit mendicancy. Yet the police were equally aware that not all beggars were spurious, and some felt that better provisions welfare facilities were required.

\section{IV.}

Indeed, in the final analysis, what is often readily apparent in police memoirs is not only the extent of the daily contact between the police and the poor of all types, but also the subsequent sympathy and respect for the latter that this engendered. French police authors were by no means overly sentimental, yet many still convey a sense of their familiarity with the poor, a certain intimation of respect for those who remained 'honest' and overall (vagrants excepted), a distinct lack of prejudice. Goron noted that after first joining the force, little by little he was initiated into the sad underbelly of Paris ${ }^{73}$. Recounting his first visit to Les Halles at night, he recalls that he was struck by the «small number of crimes which were committed in this place where men and women, working at night, were obliged to resort to alcoholic

Forestier (1983, p. 69).

Bent (1891, p. 268).

Boué (1906, p. 60), «ce sont les refuges et les hospices qu'il faudrait ouvrir et non les prisons». Smith (1997, p. 1004).

73 Goron $(1897$, p. 51), «petit nombre de crimes qui se commettent dans ce milieu d'hommes et femmes, travaillant la nuit, obligés, pour se réchauffrer l'hiver, d'absorber des boissons alcooliques». 
drinks to keep themselves warm in winter ». Despite the rigours of their daily existence, he noted respectfully that this famished population was not intrinsically criminal either by instinct or due to need.

Obviously the historian must always remain mindful of the nature of such source material. Police writers sought to convey to their readers the image of a hardened professional, fully conversant with the secrets of urban rookeries, recognised and respected in areas where the middle classes feared to tread. Yet it still does seem likely that some of the French police were privy to a more pragmatic, street-level view of the poorer districts than the middle-class theorists and undercover newspaper reporters who formed their blanket impressions over the course of a few days and then left again $^{74}$.

Sentiments of familiarity with the plight of the poor, and indeed sympathy, are even more pronounced in English police memoirs. Leeson, for example, cites a case where he arrived at the address of a criminal on the run and found that « there, to that small ten foot square room, where poverty and hunger were constant visitors, another visitor had come - grim death $" 75$. The youngest child of the family had died and when word had reached the fugitive, he had immediately returned home. The sight had a profound effect on Leeson who recalls «I felt choked, «I'm sorry Jerry », I said, as I turned to go». The fact that Leeson was on first name terms with the criminal and that such a poignant episode took place at the individuals home, combined with the officer's evident sympathy, all convey an impression of mutual respect. Leeson does not recount whether he returned later to make an arrest, but it seems hard to doubt that the continual exposure of the police to such affecting glimpses into the lives of the poor can have been wholly without effect.

Other officers cited their own efforts to assist the poor in more practical ways. Divall claimed that it had "always been my habit when I had poor persons in custody to ask them if I could get witnesses for them to help them in any way ${ }^{76}$. If such witnesses were forthcoming, «no matter where they lived», he would then see to it that their travelling expenses to the court were paid. However, where the issue of practical assistance to the poor is concerned, the example of Superintendent Bent stands out. In many of his own narratives he portrays himself as harsh and unwavering, yet in the face of genuine need he often felt compelled to act. On one particular occasion, when intending to arrest a woman accused of theft, after fighting through the snow to get to the cellar where she lived he found three small children standing in the gloom before a tiny fire. On approaching them he observed that each one had a potato peeling hanging on the bar, and from their appearance he could «easily see that these peelings, which the poor children were trying to roast, must have been taken from a neighbouring ashpit ${ }^{77}$. Bent then relates how he immediately went and purchased bread and other small items of food and placed them in the cupboard, «telling the children to let their mother know when she returned from work that the [Poor Law] relieving officer had called». Like Leeson, he does not

74 Lurid newspaper «exposés » conducted by disguised reporters were common in both countries. Such articles were generally designed to shock and based on the flimsiest of evidence. See, for example, the series «La Misère à Paris» in Gagne Petit, beginning 18/4/85. For England see Clerkenwell Weekly, 31/10/91.

76 Divall (1929, p. 112).

77 Bent (1891, p. 128). 
relate whether he subsequently returned to finish his investigations and such incidents are usually impossible to verify from other sources, yet in the case of Bent other evidence does seem to suggest a genuine humanitarianism. In particular, during the winter of 1878 he instigated a soup kitchen in the drill hall at Old Trafford Police station. At first he merely intended to feed around twenty destitute children whom he had met on his beat, but on the second day 180 presented themselves, and by the third this number had risen to 580 . This charitable work continued into well his retirement. A report from the Manchester Courier in 1888 noted that between 1,500 and 2000 meals were provided daily and described his efforts as « of very substantial advantage to a genuinely necessitous and usually deserving class ${ }^{78}$.

Bent was not unique. Other police officers (Jervis, for example) also ran soup kitchens and made charitable collections until well into the twentieth century. In France too, Andrieux detailed his efforts to secure an annual budget of 60,000 francs to assist those among the poor who were behind with their rent and in danger of eviction, noting that «it is a distressing spectacle when one sees these unfortunates, with their children, afraid in the midst of their old rags and mattresses thrown out on the pavement ${ }^{79}$. Such activities well have been inspired as much by a common-sense attempt to remain on friendly terms with the frequent object of police investigations as by altruism. Yet while such individuals were not perhaps the norm either, it seems likely that the realism and practicality of the police were tinged with sympathy more often than might at first be expected ${ }^{80}$.

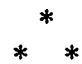

When analysing the memoirs, autobiographies and policing manuals of ex-officers, a high degree of scepticism must be utilised. Such works were usually sold on the basis of the «excitement factor » of the crimes they detailed, rather than on interest in the individual officials concerned, and this necessarily raises the spectre of embellishment and caricature. However, the fact that many authors preferred to dwell principally on the more sensational, high-profile crimes of their careers, and often mentioned the poor only incidentally, perhaps indicates that such detail is less likely to have been exaggerated and can be more fully relied upon. Yet while French memoirs tended towards the theoretical classification of criminals, and the English genre was perhaps more anecdotal, both do have an obvious propensity towards generalisation. As Peter Becker has noted in the case of Germany, police opinions in such matters were «usually not the product of some protracted research effort, but rather a rationalisation of their own practical experience and observations in the field of policing » in which they «knowingly generalised their findings without hesitation ${ }^{81}$.

Moreover, even when authoritative, the works discussed here are really only indicative of attitudes and opinions. Although the genre had developed considerably

\footnotetext{
78 Manchester Courier, $23^{\text {rd }}$ March 1888.
}

79 Andrieux (1885, p. 331), «c'est un désolant spectacle que celui de ces malheureux qu'on voit, avec leurs enfants, pleurant au milieu de leurs hardes et de leurs matelas jetés sur le pavé».

80 See also Davis (1994) for information on the social assistance role of the police courts in England.

81 Becker (1994, p. 79). 
from the ghost-writing fiascos of the Vidocq era, the historian must be aware of claims that the actions of the police in fact ran counter to their literary self-portrayal. Yves Guyot, for example, in his study of the French police in the 1880s, alleged that many police commissaires did not respect the poor and that they «had a constant tendency to believe a well-off, sober individual, over one who is badly turned out ${ }^{82}$. Certainly more research is required before an accurate assessment of the operational treatment of the poor is unveiled but despite this, most of the officers whose memoirs have been considered here were eventually senior officials, with long careers, and hence the perceptions of the poor they held cannot fail to have had some practical relevance.

In general it appears that police officers on both sides of the Channel held an extremely realistic and pragmatic conception of the poor, neither overdramatising or romancing their situation. Certainly most were of the opinion that the poor were responsible for much of the crime they policed, but were equally quick to acknowledge that other types of crime and criminality did exist. Reflecting the opinions of contemporary social commentators, most ex-officers rejected simple economic determinism as an explanation for indigent criminality. Given levels of police involvement with drunkenness as a public order offence it is unsurprising that some emphasised alcohol abuse as a cause of both poverty and crime, although others were perhaps clear-sighted enough to realise that in many cases the predilection for drink was more a side-effect of extreme destitution than its cause. Perhaps more common, especially towards the end of the century, was an emphasis on the more collective pressures of the urban environment. The poor were perceived to be driven into the arms of criminality by a combination of unemployment, enforced proximity to hardened recidivists and the moral and physical decay which inevitably resulted from their perpetual lack of resources. A particular concern on both sides of the channel was the extent to which new generations of poor children were continually corrupted, renewing the 'criminal classes' from the bottom up.

The social background of police recruits may have been a factor in this somewhat unexpected discernment. Certainly in England police recruits were often more than familiar with the plight of the poor, being but little removed from them socially in many cases. When Sir Robert Peel formed the Metropolitan Police in 1829 he specified that constables were to be drawn from the working class and could subsequently move into the senior ranks. Emsley and Clapson confirm that police forces nation-wide "drew heavily on the unskilled and semi-skilled working class ${ }^{83}$. In France too, although the military laws of 1872,1889 and 1905 meant that a large proportion of police posts were reserved for ex-soldiers, policing was by no means considered a prestigious career. Berlière notes that it was not until Lépine's reforms of 1894, which increased the wages of the Paris Police by $50 \%$ and introduced clothing and housing allowances, that levels of resignation began to fall ${ }^{84}$. It is thus likely that in France too, those enrolling in the police were initially drawn from the lower end of the social spectrum. Given this, it is perhaps understandable that the police in both countries adopted a more enlightened view of indigent criminality than certain other social commentators.

82 Guyot (1881, p. 96-98), « ont une tendance constante à donner raison à l'individu bien posé, à l'aise, contre celui qui ne présente pas de surface».

83 Emsley and Clapson (1994, p. 283). See also the work of Klein (1992).

84 Berlière (1996). 
However, despite their earnest literary expressions of concern, as Stefan Petrow notes of the Metropolitan Police, «moral considerations rarely preoccupied the minds of most policemen. They were concerned with practical matters $"{ }^{85}$. A large tranche of police time was taken up with the systematic supervision of vagrants and beggars. While the English police found their contact with vagrants as Poor Law Relieving Officers distasteful, antipathy towards such individuals and their perceived criminality was rather more pronounced among the French police, possibly because the lack of an alternative welfare infrastructure meant that the problem remained largely theirs alone until the twentieth century. Here the police were often caught between the demands of their superiors, indicative of middle class anxieties, and the dictates of practicality. Officers often noted that there was little point in arresting tramps, as they were usually re-released by magistrates almost immediately $^{86}$. Where mendicity was concerned, police attitudes again converged. Sympathy was expressed for cases of genuine need, but this was tempered by a hard-headed awareness of the activities of professional beggars. Yet, these specific groups aside, understanding combined with realism in the attitudes of the police to the «honest » or «deserving » poor. Familiarity, it appears, did not breed contempt, but - in general - a measure of understanding restrained by the dictates of realism and practicality.

\author{
Paul Lawrence \\ History Department \\ The Open University \\ Walton Hall \\ Milton Keynes MK7 6AA \\ United Kingdom \\ P.M.Lawrence@open.ac.ak
}

\title{
References
}

Andrieux, L., Souvenirs d'un préfet de police, Tome I, Paris, 1885.

Becker, P., Changing images: The criminal as seen by the German police in the nineteenth

Century, History of European Ideas, 1994, Vol.19, No.s 1-3, pp. 79-85.

Berlière, J-M., L'institution policière en France sous la Troisième République, 1875-1914, Thèse pour le Doctorat, 1991.

Berlière, J-M., Le préfet Lépine. Vers la naissance de la police moderne, Paris, Denoël, 1993. Berlière, J-M., Le monde des polices en France, Paris, Éditions Complexe, 1996.

Bent, Superintendent J., Criminal Life: Reminiscences of Forty-Two Years as a Police Officer, Manchester, 1891.

Boué, P., Vagabondage et mendicité. Moyens de défense, Paris, 1906.

Caubet, Souvenirs (1860-1889), Paris, 1893.

Chadwick, W., Reminiscences of a Chief Constable, Manchester, 1900.

Clay, Rev. J., Chaplains Report on the Preston House of Correction, Preston, 1853.

85 Petrow $(1994$, p. 220).

86 See, for example, Andrieux (1885, p. 63). 
Davis, J., Urban policing and its objects: Comparative themes in England and France in the second half of the nineteenth century, in Emsley, C., and Weinberger, B., et al. (eds.), Policing Western Europe: Politics, Professionalism and Public Order, 1850-1940, London, 1991.

Davis, J., A poor man's system of justice: The London police courts in the second half of the nineteenth century, The Historical Journal, 1984, 27,2, p. 309-335.

Despine, P.C., Le démon alcool. Ses effets désastreux sur le moral, sur l'intelligence et sur le physique. Moyens d'y porter remède, Paris, 1871.

Divall, T., Scoundrels and Scallywags (and some honest men), London, 1929.

Emsley, C., Crime and Society in England, 1750-1900, London, Longman, 1996, a.

Emsley, C., The English Police: A Political and Social History, London, Longman, 1996, b.

Emsley, C., \& Clapson, M., Recruiting the English policeman c.1840-1940, Policing and Society, 1994, vol. 3, pp. 269-286.

Englander, D., Poverty and Poor Law Reform in 19 $9^{\text {th }}$ Century Britain, 1834-1914.From Chadwick to Booth, London, Longman, 1998.

Féré, C., Dégénérescence et criminalité, Paris, 1888.

Forestier, I-E., Gendarmes à la Belle Époque, Paris, 1983.

Frégier, H.A., Des classes dangereuses de la population dans les grandes villes et des moyens de les rendre meilleures, Bruxelles, 1840.

Gaboriau, P., SDF à la Belle Époque, Paris, Descler de Brouwer, 1998.

Goron, M., Les mémoires de M. Goron, ancien chef de la Sûreté. I. De l'invasion à l'anarchie, Paris, 1897.

Guyot, Y., La police - Études de physiologie sociale, Paris, 1881.

Hamon, L., Police et criminalité - Impressions d'un vieux policier, Paris, 1900.

Hoyle, W., Crime in England and Wales in the Nineteenth Century. An Historical and Critical Retrospective, London, 1876.

Inwood, S., Policing London's morals: The metropolitan police and popular culture, 1829 1850, The London Journal, 1990, 15 (2), p. 129-146.

Jervis, R., Lancashire's Crime and Criminals - With some Characteristics of the County, Southport, 1908.

Joly, H., La France criminelle, Paris, 1889.

Jones, D., Crime, Protest, Community and Police in $19^{\text {th }}$ Century Britain, London, Routledge \& Kegan Paul, 1982.

Kalifa, D., Concepts de défense sociale et analyses du fait délinquant dans la France du début du XX' $\mathrm{XX}^{\mathrm{c}}$ siècle, in Garnot, B., (Dir.), Ordre moral et délinquance de l'antiquité au XX siècle. Actes du colloque de Dijon 7 et 8 Octobre 1993, Dijon, EUD, 1994, p. 233-40.

Klein, J., Invisible Working class Men: Police Constables in Manchester, Birmingham and Liverpool, 1900-1939, doctoral thesis, Rice University, 1992.

Leeson, Sergeant B., Lost London - The Memoirs of an East End Detective, London, 1931.

Lucassen, L., «Harmful Tramp» police professionalization and gypsies in Germany, 17001945, in Crime, Histoire \& Sociétés, 1997, nº 1, vol. 1, pp.29-50.

Macé, G., Le service de la Sûreté, Paris, 1885.

Macé, G., Un joli monde, Paris, 1887.

Macé, G., Paris Unveiled, or an Expose of Vice and Crime in the Gay French Capital By a Celebrated French Detective, translated by Richard K.Fox, New York, 1888.

Morrison, Reverend W.D., Juvenile Offenders, London, 1896.

Niceforo, A., La police et l'enquête judiciaire scientifique, Paris, 1907. 
Peek, F., Social Wreckage-A Review of the Laws of England as they Affect the Poor, London, 1883.

Petrow, S., Policing Morals: The Metropolitan Police and the Home Office, 1870 -1914, Oxford, Clarendon Press, 1994.

Pick, D., Faces of Degeneration. A European Disorder, c.1848-c.1918, Cambridge, Cambridge University Press, 1989.

Schwartz, R., Policing the Poor in Eighteenth-Century France, Chapel Hill, London, University of North Carolina Press, 1988.

Smith, Timothy B., The ideology of charity, The image of the English poor law, and debates over the right to assistance in France, 1830-1905, The Historical Journal, 1997, 40 (4), p. 997-1032.

Stedman Jones, G., Outcast London - A Study in the Relationship between Classes in Victorian Society, Harmondsworth, Penguin, 1976.

Storch, R., The policeman as Domestic missionary: Urban discipline and popular culture in Northern England, 1850-1880, Journal of Social History, 1976, IX, p. 481-511.

Tallack, W., The Problem of Diminishing Prevalent Destitution and Temptations to Crime, London, 1869.

Thompson, F.M.L., Social control in Victorian Britain, The Economic History Review, May 1981, Second Series, Vol. XXXIV, No. 2, p. 188-208.

Veitl, P., Henri Joly et le «criminel déraciné», in Garnot, B., (Dir.), Ordre moral et délinquance de l'antiquité au XX $X^{e}$ siècle. Actes du colloque de Dijon 7 et 8 Octobre 1993, Dijon, EUD, 1994, p. 215-24.

Wagniart, J-F, Le vagabond à la fin du XIX $X^{e}$ siècle, Paris, Éditions Belin, 1999.

Wensley, F.P., Detective Days. The Record of Forty Two Years Service in the CID, London, 1931. 